DOI: https://doi.org/10.24127/ajpm.v8i2.1947

\title{
ANALISIS KEMAMPUAN BERPIKIR KRITIS MAHASISWA DALAM MEMECAHKAN MASALAH KALKULUS
}

\author{
Yunis Sulistyorini ${ }^{1}$, Siti Napfiah ${ }^{2}$ \\ ${ }^{1,2}$ Pendidikan Matematika, IKIP Budi Utomo Malang \\ E-mail: $\quad$ yunis.sulistyorini@gmail.com ${ }^{11}$ \\ $\underline{\text { napfiahsiti@gmail.com }}^{\text {L) }}$
}

Received 26 April 2019; Received in revised form 14 October 2019; Accepted 28 October 2019

\begin{abstract}
Abstrak
Berpikir kritis merupakan kemampuan yang dapat dipelajari dan dilatihkan agar mampu memecahkan masalah secara efektif. Penelitian ini bertujuan untuk mendeskripsikan kemampuan berpikir kritis mahasiswa dalam memecahkan masalah kalkulus. Jenis penelitian ini adalah penelitian kualitatif deskriptif. Subjek dari penelitian ini adalah tiga orang mahasiswa program studi Pendidikan Matematika IKIP Budi Utomo Malang yang berkemampuan matematika tinggi. Instrumen yang digunakan yaitu soal pemecahan masalah Kalkulus dan pedoman wawancara. Instrumen dibuat untuk menggali kemampuan berpikir kritis mahasiswa dalam memecahkan masalah. Hasil penelitian menunjukkan bahwa subjek mampu menunjukkan kemampuan berpikir kritis yang tinggi. Hal ini ditunjukkan dengan terpenuhinya seluruh indikator kemampuan berpikir kritis dalam memecahkan masalah matematika yaitu menggunakan penalaran pada tahap memahami masalah, menganalisis keterkaitan masing-masing bagian dari keseluruhan untuk menghasilkan sistem yang kompleks pada tahap membuat perencanaan, menganalisis dan mengevaluasi fakta-fakta pada tahap melaksanakan perencanaan, dan menarik kesimpulan berdasarkan hasil analisis pada tahap memeriksa kembali. Walaupun ketiga subjek memenuhi keseluruhan indikator berpikir kritis, namun masing-masing subjek menunjukkan proses pemecahan masalah yang berbeda. Masalah open-ended dapat dipertimbangkan dalam melatihkan kemampuan berpikir kritis sekaligus mengakomodasi berbagai tingkatan akademik mahasiswa.
\end{abstract}

Kata kunci: berpikir kritis; pemecahan masalah; kalkulus

\begin{abstract}
Critical thinking is an ability that can be learned and trained to be able to solve problems effectively. This study aims to describe students' critical thinking skills in solving calculus problems. This type of study was descriptive qualitative research. The subjects were three undergraduate students of the IKIP Budi Utomo Malang Mathematics Education with high mathematical abilities. The research instruments were calculus problem solving questions and interview guidelines. The instruments used to explore students' critical thinking skills in solving problems. The results showed that subjects were able to demonstrate high critical thinking skills. This is indicated by the fulfillment of all indicators of critical thinking skills in solving mathematical problems, namely using reasoning at the stage of understanding the problem, analyzing the relationship of each part of the whole to produce a complex system at the stage of devising a plan, analyzing and evaluating the facts at the stage of carrying out the plan, and draw conclusions based on the results of the analysis at the stage of looking back. Although all three subjects fulfill all indicators of critical thinking skills, each subject shows a different problem solving process. Open ended problems can be considered to develop critical thinking skills while accommodating various academic levels of students.
\end{abstract}

Keywords: Calculus; critical thinking; problem solving.

\section{PENDAHULUAN}

Di era milenial yang penuh dengan persaingan ini, berpikir kritis mempunyai peran penting dalam menghadapi aneka macam masalah dalam kehidupan. Dalam hal ini pendidikan merupakan salah satu fasilitas yang sangat mendukung untuk melatih pola pikir kritis para calon generasi masa depan. Hal ini sependapat dengan yang dikatakan Sulistiani \& Masrukan (2016) bahwa salah satu upaya yang dapat dilakukan untuk meningkatkan sumber daya manusia yaitu dengan meningkatkan kualitas pendidikan yang berfokus pada pengembangan kemampuan berpikir kritis pembelajar. Begitu pula yang dikatakan Firdaus, dkk. (2015) bahwa kemampuan 
berpikir kritis diperlukan untuk kesuksesan pembelajar di masa depan. Dengan demikian, para pembelajar sebaiknya dituntut untuk memiliki kemampuan berpikir kritis.

Terdapat berbagai macam pengertian berpikir kritis. Berpikir kritis adalah berpikir reflektif dan masuk akal yang difokuskan pada memutuskan apa yang harus dipercaya atau dilakukan (Ennis, 2015). Komponen pada berpikir kritis meliputi kemampuan dalam menganalisis argumen, membuat kesimpulan menggunakan alasan yang induktif dan deduktif, mengevaluasi, dan membuat keputusan (Lai, 2011). Selain itu, Caroselli (2009) juga mengatakan bahwa pemikir kritis tidak hanya dapat menjawab sesuai dengan logika yang benar, tetapi juga menyelesaikan masalah. Dengan demikian, setiap orang sebaiknya mengembangkan pola pikir kritis agar dapat menghadapi aneka macam masalah dengan tepat. Adapun indikator berpikir kritis yakni mengidentifikasi, menghubungkan, menganalisis, dan memecahkan masalah matematika (Palinussa, 2013). Sedangkan Yuniar, dkk (2017) mengatakan bahwa indikator berpikir kritis yaitu (1) menggunakan penalaran induktif atau penalaran deduktif, (2) menganalisis keterkaitan masing-masing bagian dari keseluruhan untuk menghasilkan sistem yang kompeks, (3) menganalisis dan mengevaluasi fakta-fakta, (4) menarik kesimpulan berdasarkan hasil analisis, (5) menyelesaikan masalah yang tidak biasa/umum dengan cara konvensional maupun inovatif.

Berpikir kritis mengarahkan seseorang untuk mampu memecahkan masalah dengan efektif (Peter, 2012). Pola pikir kritis dapat dilatih atau dikembangkan dalam kegiatan pembelajaran. Kemampuan berpikir kritis pembelajar dapat dilatih dengan cara dimunculkannya berbagai macam masalah dalam pembelajaran. Seperti yang diungkapkan Belecina \& Ocampo (2018) bahwa penggunaan berbagai situasi masalah dapat meningkatkan kemampuan berpikir kritis pembelajar. Selain itu, belajar untuk berpikir kritis mengarahkan pembelajar untuk mengembangkan kemampuan lain seperti tingkat konsentrasi yang lebih baik, kemampuan analisis yang lebih dalam, dan peningkatan proses berpikir (Van Roekel, 2014). Dengan demikian, pengajar mempunyai peran penting untuk mengembangkan berpikir kritis para pembelajar. Cara yang dapat dilakukan yaitu sesering mungkin memberikan soalsoal berupa masalah yang dalam mencari penyelesaiannya dituntut untuk berpikir kritis.

Pada Matematika, Kalkulus merupakan materi yang cukup penting untuk dipelajarai. Terlebih ada banyak penggunaan Kalkulus dalam kehidupan. Di program studi Pendidikan Matematika IKIP Budi Utomo Malang, terdapat tiga mata kuliah jenis Kalkulus yakni Kalkulus Diferensial, Kalkulus Integral, dan Kalkulus Peubah Banyak. Materi Kalkulus dibagi menjadi tiga mata kuliah seperti itu dikarenakan begitu pentingnya mahasiswa perlu memahami materi Kalkulus secara mendalam. Kalkulus dasar yang terdiri dari Kalkulus Diferensial dan Kalkulus Integral ini ditempuh mahasiswa pada tahun pertama. Penelitian dari Mugisha, dkk (2014) berfokus pada performa mahasiswa tahun pertama pada materi Kalkulus. Performa tersebut dijabarkan melalui asesmen terhadap pentingnya memahami masalah, mengenali apa yang diinginkan, merancang strategi penyelesaian, menerapkan strategi, keragu-raguan, kejujuran dan menunjukkan kemampuan dalam proses penyelesaian. Jadi penelitian ini belum sepenuhnya membahas bagaimana kemampuan berpikir kritis dalam memecahkan masalah Kalkulus. Di lain 
pihak, penelitian dari Palupi, dkk. (2017) sudah berfokus pada bagaimana kemampuan berpikir kritis dalam memecahkan masalah. Namun, penelitian belum berfokus pada materi Kalkulus. Dari hasil penelitian Palupi, dkk. (2017) juga diketahui bahwa sebagian besar subjek belum mampu berpikir kritis.

Hal yang sama juga ditunjukkan berdasarkan observasi yang dilakukan terhadap mahasiswa program studi Pendidikan Matematika IKIP Budi Utomo Malang. Diketahui bahwa sebagain besar kemampuan Kalkulus mahasiswa termasuk menengah ke bawah. Hanya beberapa mahasiswa yang memiliki pemahaman dengan baik. Biasanya mahasiswa yang memiliki kemampuan baik tersebut, dalam kesehariannya termasuk mahasiswa yang aktif untuk bertanya dimana mereka menggunakan pola pikir kritisnya ketika diberikan penjelasan materi oleh dosen. Mengingat pentingnya kemampuan berpikir kritis, setiap mahasiswa sudah seharusnya mengembangkan kemampuan berpikir kritisnya.

Kemampuan berpikir kritis sendiri merupakan kemampuan yang dapat dilatihkan (Peter, 2012). Untuk melatihkan kemampuan berpikir kritis tidak dapat terlepas dari peran pengajar. Untuk mampu melatihkan kemampuan berpikir kritis, pengajar memerlukan gambaran bagaimana kemampuan berpikir kritis mahasiswanya, terutama yang berkemampuan akademik tinggi. Peserta didik yang berkemampuan tinggi tidak akan menurun performanya jika harus bekerja sama dengan siswa berkemampuan rendah, peserta didik yang berkemampuan sedang juga dapat bekerja sama secara maksimal asalkan mereka berada dalam satu kelompok atau dalam kelompok yang berkemampuan berbeda, dan peserta didik yang berkemampuan rendah tidak akan mampu berpartisipasi secara maksimal jika mereka berada dalam kelompok yang juga berkemampuan rendah (Huda, 2012). Jadi dalam hal ini, mahasiswa yang berkemampuan akademik tinggi salah satunya dapat dijadikan sebagai acuan bagi pengajar dalam mengevaluasi, mengelola dan memperbaiki pembelajaran.

Berdasarkan uraian tersebut, penelitian bertujuan untuk mendeskripsikan kemampuan berpikir kritis mahasiswa dalam memecahkan masalah Kalkulus. Penelitian dilakukan terhadap mahasiswa tahun pertama yang menempuh materi Kalkulus. Analisis kemampuan berpikir kritis ini difokuskan pada mahasiswa berkemampuan akademik tinggi untuk memperoleh gambaran sampai sejauh mana indikator kemampuan berpikir kritis dapat dipenuhi dalam memecahkan masalah.

\section{METODE PENELITIAN}

Jenis penelitian ini merupakan penelitian kualitatif deskriptif. Tujuan dari penelitian ini adalah mendeskripsikan kemampuan berpikir kritis dalam memecahkan masalah matematika. Penelitian hanya dibatasi pada materi Kalkulus Integral, yaitu jumlah Riemann. Subjek penelitian adalah mahasiswa program studi Pendidikan Matematika IKIP Budi Utomo Malang. Subjek penelitian hanya dibatasi pada mahasiswa yang berkemampuan akademik tinggi yang terdiri dari tiga orang. Tiga orang mahasiswa ini masing-masing mewakili tiga kelas berbeda dalam pembelajaran Kalkulus. Penelitian hanya melibatkan mahasiswa berkemampuan tinggi untuk memperoleh gambaran sampai sejauh mana indikator kemampuan berpikir kritis sudah dipenuhi dalam memecahkan masalah. Gambaran ini digunakan sebagai acuan dan bahan pertimbangan bagi pengajar untuk melatihkan kemampuan 
DOI: https://doi.org/10.24127/ajpm.v8i2.1947

berpikir kritis dalam pembelajaran di kelas.

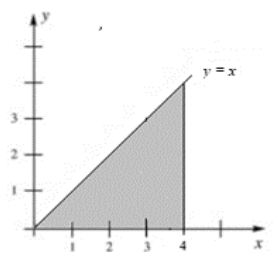

Gambar 1. Soal Pemecahan Masalah

Instrumen dalam penelitian adalah tes pemecahan masalah dan pedoman wawancara. Tes pemecahan masalah mengacu pada indikator kemampuan berpikir kritis. Indikator kemampuan berpikir kritis adalah (1) menggunakan penalaran, (2) menganalisis keterkaitan masing-masing bagian dari keseluruhan untuk menghasilkan sistem yang kompleks, (3) menganalisis dan mengevaluasi fakta-fakta, dan (4) menarik kesimpulan berdasarkan hasil analisis. Soal dalam tes ini adalah (1) Pilihlah sebarang $n$ untuk mengestimasi nilai sesungguhnya dari luas daerah di bawah kurva dengan jumlah Riemann. (2)
Tentukan luas daerah di bawah kurva yang sesungguhnya seperti dalam Gambar 1.

Sedangkan pedoman wawancara digunakan untuk menggali lebih dalam informasi tentang masing-masing indikator kemampuan berpikir kritis mahasiswa dalam memecahkan masalah kalkulus. Hasil wawancara kemudian ditriangulasikan dengan hasil tes pemecahan masalah sebelumnya sehinga diperoleh deskripsi kemampuan berpikir kritis mahasiswa dalam memecahkan masalah kalkulus.

\section{HASIL PENELITIAN DAN PEMBAHASAN}

Deskripsi kemampuan berpikir kritis ketiga subjek yang masing-masing merupakan mahasiswa berkemampuan akademik tinggi mengacu pada Tabel 1.

Tabel 1. Deskripsi Indikator Kemampuan Berpikir Kritis dalam Pemecahan Masalah Kalkulus

\begin{tabular}{|c|c|c|}
\hline $\begin{array}{c}\text { Pemecahan } \\
\text { Masalah }\end{array}$ & $\begin{array}{c}\text { Indikator Kemampuan } \\
\text { Berpikir Kritis }\end{array}$ & Deskripsi \\
\hline $\begin{array}{l}\text { Memahami } \\
\text { masalah }\end{array}$ & $\begin{array}{l}\text { Menggunakan penalaran } \\
\text { induktif atau deduktif }\end{array}$ & $\begin{array}{l}\text { 1. Memilih sebarang } n \text { untuk } \\
\text { mengestimasi luas daerah di bawah } \\
\text { kurva dan menjelaskan alasan } \\
\text { pemilihan } \mathrm{n} \text { tersebut } \\
\text { 2. Menentukan dan menjelaskan bahwa } \\
\text { luas daerah di bawah kuva dapat } \\
\text { diperoleh dengan menghitung luas } \\
\text { segitiga atau menerapkan integral } \\
\text { tentu }\end{array}$ \\
\hline $\begin{array}{l}\text { Membuat } \\
\text { perencanaan }\end{array}$ & $\begin{array}{l}\text { Menganalisis } \\
\text { keterkaitan masing- } \\
\text { masing bagian dari } \\
\text { keseluruhan untuk } \\
\text { menghasilkan sistem } \\
\text { yang kompleks }\end{array}$ & $\begin{array}{l}\text { 1. Menentukan partisi masing-masing } \\
\text { interval berdasarkan sebarang } n \text { yang } \\
\text { sudah dipilih untuk menentukan lebar } \\
\text { dan panjang masing-masing persegi } \\
\text { panjang } \\
\text { 2. Mengidentifikasi bagian-bagian pada } \\
\text { kurva untuk menentukan alas dan } \\
\text { tinggi segitiga atau formula dalam } \\
\text { integral tentu }\end{array}$ \\
\hline
\end{tabular}


DOI: https://doi.org/10.24127/ajpm.v8i2.1947

\begin{tabular}{|c|c|c|}
\hline $\begin{array}{l}\text { Pemecahan } \\
\text { Masalah }\end{array}$ & $\begin{array}{l}\text { Indikator Kemampuan } \\
\text { Berpikir Kritis }\end{array}$ & Deskripsi \\
\hline $\begin{array}{l}\text { Menerapkan } \\
\text { perencanaan }\end{array}$ & $\begin{array}{l}\text { Menganalisis dan } \\
\text { mengevaluasi fakta- } \\
\text { fakta }\end{array}$ & $\begin{array}{l}\text { 1. Menghitung jumlah Riemann } \\
\text { berdasarkan partisi } n \text { untuk } \\
\text { mengestimasi luas daerah di bawah } \\
\text { kurva } \\
\text { 2. Menghitung luas segitiga berdasarkan } \\
\text { alas (lebar interval) dan tinggi (nilai } \\
\text { fungsi) atau menerapkan integral } \\
\text { tentu untuk menentukan luas } \\
\text { sebenarnya di bawah kurva }\end{array}$ \\
\hline $\begin{array}{l}\text { Memeriksa } \\
\text { kembali }\end{array}$ & $\begin{array}{l}\text { Menarik kesimpulan } \\
\text { berdasarkan hasil } \\
\text { analisis }\end{array}$ & $\begin{array}{l}\text { Menjelaskan hubungan antara jumlah } \\
\text { Riemann dan luas daerah di bawah } \\
\text { kurva }\end{array}$ \\
\hline
\end{tabular}

\section{Subjek 1}

Pada tahap memahami masalah subjek mampu melakukan penalaran dengan baik. Subjek mampu memilih sebarang $n$ dan menjelaskan alasan pemilihan $n$ tersebut. Bahkan subjek memberikan tiga pemilihan $n$, yaitu $n=2$, $n=4$ dan $n=8$ dan memberikan tiga alternatif pemecahan dengan menggunakan Riemann kanan, kiri dan titik tengah untuk menjelaskan perbandingan di antara ketiga pilihan tersebut dalam mengestimasi luas daerah di bawah kurva. Subjek juga mampu menjelaskan bahwa luas daerah di bawah kurva dapat diperoleh dengan menghitung luas segitiga. Jadi, subjek memenuhi indikator yang pertama yaitu mampu menggunakan penalaran.

Pada tahap membuat perencanaan, subjek mampu menentukan partisi masing-masing interval $n=2, n=4$ dan $n=8$ sehingga diperoleh lebar dan panjang masing-masing persegi panjang. Subjek juga mampu menentukan alas dan tinggi segitiga dan menjelaskan alasannya setelah mengidentifikasi bagian dari kurva. Jadi, subjek memenuhi indikator yang kedua yaitu menganalisis keterkaitan masing-masing bagian dari keseluruhan untuk menghasilkan sistem yang kompleks.
Pada tahap melaksanakan perencanaan, subjek mampu menghitung jumlah Riemann berdasarkan partisi pada langkah sebelumnya untuk mengestimasi luas daerah di bawah kurva. Subjek juga mampu menghitung luas segitiga dengan benar untuk menentukan luas sebenarnya di bawah kurva. Jadi, subjek memenuhi indikator yang ketiga yaitu menganalisis dan mengevaluasi fakta-fakta.

Pada tahap memeriksa kembali, subjek mampu menjelaskan bahwa alternatif yang paling baik untuk mengestimasi luas daerah di bawah kurva pada masalah ini adalah dengan menggunakan Riemann yang menerapkan titik tengah. Jadi, subjek memenuhi indikator yang keempat yaitu menjelaskan hubungan antara jumlah Riemann dan luas daerah di bawah kurva.

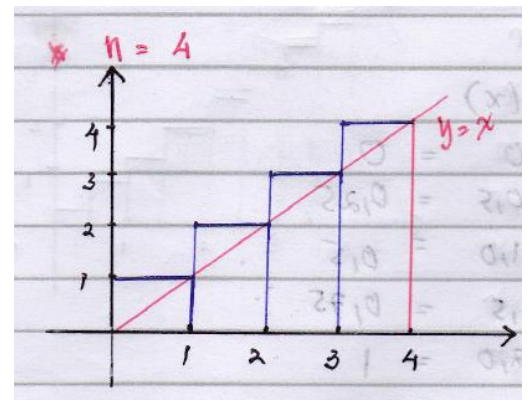

Gambar 2. Partisi $n=4$ oleh Subjek 1 
DOI: https://doi.org/10.24127/ajpm.v8i2.1947

\section{Subjek 2}

Pada tahap memahami masalah, subjek mampu melakukan penalaran dengan baik. Subjek mampu memilih sebarang $n$ dan menjelaskan alasan pemilihan $n$ tersebut. Dalam hal ini subjek memilih $n=6$. Subjek juga mampu menjelaskan bahwa luas daerah di bawah kurva dapat diperoleh dengan menghitung luas segitiga. Jadi, subjek memenuhi indikator yang pertama yaitu mampu menggunakan penalaran.

Pada tahap membuat perencanaan, subjek mampu menentukan partisi masing-masing interval dengan $n=6$ yaitu $(1,1.5),(1.5,2),(2,2.5),(2.5,3),(3,3.5)$, dan $(3.5,4)$. Subjek juga mampu menentukan alas dan tinggi segitiga dan menjelaskan alasannya setelah mengidentifikasi bagian dari kurva. Jadi, subjek memenuhi indikator yang kedua yaitu menganalisis keterkaitan masingmasing bagian dari keseluruhan untuk menghasilkan sistem yang kompleks.

Pada tahap melaksanakan perencanaan, subjek mampu menghitung jumlah Riemann berdasarkan partisi pada langkah sebelumnya untuk mengestimasi luas daerah di bawah kurva. Subjek juga mampu menghitung luas segitiga dengan benar untuk menentukan luas sebenarnya di bawah kurva. Jadi, subjek memenuhi indikator yang ketiga yaitu menganalisis dan mengevaluasi fakta-fakta.

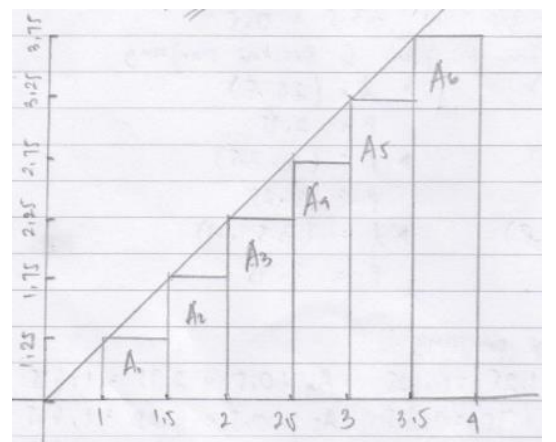

Gambar 3. Partisi $n=6$ oleh Subjek 2

Pada tahap memeriksa kembali, subjek memberikan alternatif untuk mengestimasi luas daerah di bawah kurva pada masalah ini dengan menggunakan definisi integral tentu. Subjek menjelaskan hubungan antara jumlah Riemann dan luas daerah di bawah kurva dengan mempertimbangkan integral tentu. Jadi, subjek memenuhi indikator yang keempat yaitu menjelaskan hubungan antara jumlah Riemann dan luas daerah di bawah kurva.

\section{Subjek 3}

Pada tahap memahami masalah, subjek mampu melakukan penalaran dengan baik. Subjek mampu memilih sebarang $n$ dan menjelaskan alasan pemilihan $n$ tersebut. Dalam hal ini subjek memilih $n=8$. Subjek juga mampu menjelaskan bahwa luas daerah di bawah kurva dapat diperoleh dengan menerapkan integral tentu. Jadi, subjek memenuhi indikator yang pertama yaitu mampu menggunakan penalaran.

Pada tahap membuat perencanaan, subjek mampu menentukan partisi masing-masing interval dengan $n=8$. Subjek juga mampu menentukan formula untuk menerapkan integral tentu. Jadi, subjek memenuhi indikator yang kedua yaitu menganalisis keterkaitan masingmasing bagian dari keseluruhan untuk menghasilkan sistem yang kompleks.

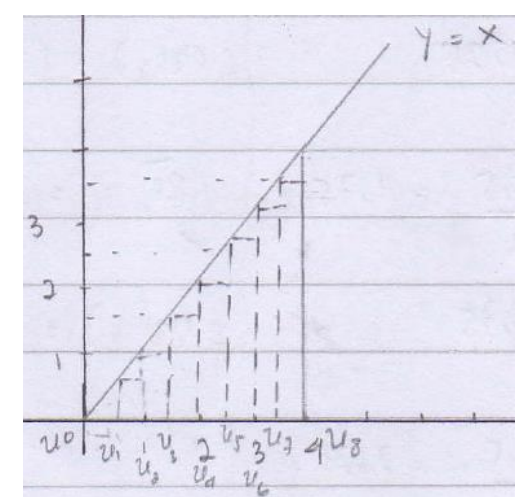

Gambar 4. Partisi $n=8$ oleh Subjek 3

Pada tahap melaksanakan perencanaan, subjek mampu menghitung jumlah Riemann berdasarkan partisi pada 
langkah sebelumnya. Subjek juga mampu menghitung integral tentu dengan benar. Jadi, subjek memenuhi indikator yang ketiga yaitu menganalisis dan mengevaluasi fakta-fakta.

Pada tahap memeriksa kembali, subjek memberikan alternatif untuk mengestimasi luas daerah di bawah kurva pada masalah ini dengan menggunakan integral tentu. Jadi, subjek memenuhi indikator yang keempat yaitu menjelaskan hubungan antara jumlah Riemann dan luas daerah di bawah kurva.

Berdasarkan hasil tes dan wawancara di atas, diperoleh bahwa subjek 1, 2 maupun 3 mampu memenuhi keseluruhan indikator kemampuan berpikir kritis. Ketiga subjek juga mampu melaksanakan mulai tahap memahami masalah hingga tahap memeriksa kembali dengan baik. Seluruh subjek yang merupakan mahasiswa berkemampuan matematika tinggi ini ternyata menunjukkan kemampuan berpikir kritis yang tinggi. Hal ini sejalan dengan yang dinyatakan oleh Purwati, dkk (2016) bahwa kemampuan berpikir kritis tinggi mampu memenuhi semua indikator yang meliputi menginterpretasi masalah, menganalisis, mengevaluasi, dan mengiferensi. Kemampuan berpikir kritis sedang hanya mampu memenuhi indikator yang meliputi menginterpretasi masalah dan menganalisis. Kemampuan berpikir kritis rendah kurang mampu memenuhi indikator menginterpretasi masalah karena hanya mampu mengidentifiasi fakta yang diberikan pada soal.

Hal yang pertama yang dapat diperhatikan bahwa walaupun ketiganya memenuhi keseluruhan indikator kemampuan berpikir kritis namun ketiga subjek memberikan pemecahan masalah yang berbeda. Hal ini mulai ditunjukkan pada indikator yang pertama, yaitu mampu menggunakan penalaran, subjek 1 memilih tiga jenis $n(2,4$, dan 8$)$, subjek
2 memilih $n=6$, dan subjek 3 memilih $n=8$. Dalam menentukan luas sebenarnya dari daerah di bawah kurva juga terdapat pilihan yang berbeda, subjek 1 memilih menerapkan luas segitiga, sedangkan subjek 2 dan 3 memilih menerapkan integral tentu.

Hal kedua yang dapat diperhatikan adalah indikator pertama yaitu menggunakan penalaran terpenuhi pada tahap memahami masalah. Jadi bagaimana subjek menggunakan penalarannya mempengaruhi bagaimana subjek memahami masalah. Selanjutnya, penalaran yang digunakan subjek dalam memahami masalah mempengaruhi bagaimana keseluruhan tahap pemecahan masalah. Dalam pembelajaran matematika, kemampuan penalaran ini berperan baik dalam pemahaman konsep dan pemecahan masalah (Ayal, dkk, 2016); Ridwan, 2017). Penalaran juga dapat dikatakan sebagai salah satu kunci untuk menunjukkan bagaimana kemampuan berpikir kritis seseorang. Kemampuan penalaran sebagai bagian utama dari kemampuan berpikir kritis mempunyai hubungan yang positif dengan kemampuan berpikir kritis itu sendiri dan prestasi akademik (Sherafat, 2015).

Selanjutnya, hal ketiga yang menarik untuk dibahas dari hasil penelitian ini adalah pemberian masalah pada subjek mampu merangsang kemampuan berpikir kritis mahasiswa. Dengan semakin sering membiasakan mahasiswa dengan pemecahan masalah maka akan mampu meningkatkan kemampuan berpikir kritisnya. Hal ini dikarenakan berpikir kritis merupakan kemampuan yang dapat dilatihkan (Peter, 2012) dan dengan pembelajaran yang berbasis masalah maka akan mampu meningkatkan kemampuan berpikir kritis (Firdaus, dkk, 2015). Selain itu, walaupun penelitian ini berfokus pada kemampuan berpikir kritis, namun masalah open- 
ended yang diberikan kepada subjek juga mampu mengembangkan kemampuan berpikir kreatif mahasiswa. Hal ini ditunjukkan pada tahap awal memahami masalah dengan indikator kemampuan berpikir kritis menggunakan penalaran bahwa subjek mampu memberikan jawaban yang berbeda dengan masingmasing penalarannya. Masalah terbuka ini dapat digunakan untuk meningkatkan kemampuan berpikir kreatif siswa dalam pembelajaran matematika (Maharani, 2014). Ketika seseorang memecahkan masalah maka mereka akan berpikir bahwa masalah tersebut bukanlah tugas yang mudah, yang merupakan tantangan untuk mengembangkan kreatifitas dan kemampuan matematika lainnya (Ayllon, dkk, 2016). Jadi berdasarkan deskripsi kemampuan berpikir kritis subjek ini dapat dijadikan salah satu dasar agar dalam pembelajaran selanjutnya pengajar lebih sering melatihkan dan melibatkan mahasiswa dengan pemecahan masalah, salah satunya masalah open-ended.

\section{KESIMPULAN DAN SARAN}

Berdasarkan hasil analisis data penelitian dan pembahasan yang telah diuraikan, subjek yang merupakan mahasiswa berkemampuan akademik tinggi mampu menunjukkan kemampuan berpikir kritis yang tinggi. Hal ini ditunjukkan dengan terpenuhinya seluruh indikator kemampuan berpikir kritis dalam memecahkan masalah matematika yaitu menggunakan penalaran pada tahap memahami masalah, menganalisis keterkaitan masing-masing bagian dari keseluruhan untuk menghasilkan sistem yang kompleks pada tahap membuat perencanaan, menganalisis dan mengevaluasi fakta-fakta pada tahap melaksanakan perencanaan, dan menarik kesimpulan berdasarkan hasil analisis pada tahap memeriksa kembali.
Walaupun masing-masing subjek sama-sama memenuhi keseluruhan indikator kemampuan berpikir kritis namun masing-masing subjek menunjukkan proses pemecahan masalah yang berbeda. Hal ini didasarkan pada penalaran masing-masing subjek yang berbeda dalam memahami masalah. Proses pemecahan masalah yang berbeda juga dapat dipengaruhi oleh masalah open-ended yang diberikan kepada mahasiswa. Sehingga dalam praktek pembelajaran selanjutnya pemberian masalah open-ended dapat dipertimbangkan dalam melatihkan kemampuan berpikir kritis sekaligus mengakomodasi berbagai tingkatan akademik mahasiswa.

Penelitian lebih lanjut dapat difokuskan untuk mengetahui hal apa saja yang mempengaruhi kemampuan berpikir kritis mahasiswa dalam memecahkan masalah. Selain itu, berdasarkan beragamnya jawaban yang diberikan oleh subjek maka penelitian selanjutnya dapat diarahkan untuk mengetahui hubungan yang lebih dalam antara kemampuan berpikir kritis dan kreatif, terutama dalam memecahkan masalah matematika. Selain itu, pengaruh pemberian masalah dalam pembelajaran juga perlu dikaji lebih dalam untuk mengetahui pengaruhnya secara positif terhadap kemampuan berpikit kritis mahasiswa.

\section{UCAPAN TERIMA KASIH}

Ucapan terima kasih penulis ucapkan kepada Kementerian Riset, Teknologi dan Pendidikan Tinggi yang telah mendukung penelitian kami melalui hibah Penelitian Dosen Pemula 2019.

\section{DAFTAR PUSTAKA}

Ayal, C. S., Kusuma, Y. S., Sabandar, J., \& Dahlan, J. A. (2016). The Enhancement of Mathematical Reasoning Ability of Junior High School Students by Applying Mind 
DOI: https://doi.org/10.24127/ajpm.v8i2.1947

Mapping Strategy. Journal of Education and Practice.

Ayllon, M., Gomez, I., \& BallestaClaver, J. (2016). Mathematical thinking and creativity through mathematical problem posing and solving. Propósitos

Representaciones.

https://doi.org/http://dx.doi.org/10.2 0511/ pyr2016.v4n1.89

Belecina, R. R, Ocampo, J. M, J. (2018). Effective Change on Students Critical Thinking in Problem Solving. Educare: International Journal for Educational Studies, 10(2), 109-118.

Caroselli, M. (2009). 50 Activities for Developing Critical Thinking Skills. Complimentary Resources from HRD Press.

Ennis, R. H. (2015). The Nature of Critical Thinking: Outline of General Critical Thinking Dispositions and Abilities. Retrieved from http://criticalthinking.net/wpcontent/uploads/2018/01/TheNature-of-Critical-Thinking.pdf

Firdaus, F., Kailani, I., Bakar, M. N. Bin, \& Bakry, B. (2015). Developing Critical Thinking Skills of Students in Mathematics Learning. Journal of Education and Learning (EduLearn).

https://doi.org/10.11591/edulearn.v9 i3.1830

Huda, M. (2012). Cooperative Learning Metode, Teknik, Struktur dan Model Terapan. Yogyakarta: Pustaka Pelajar.

Lai, E. . (2011). Critical Thinking: A Literature Review. Transfusion. https://doi.org/10.1046/j.15372995.1995.35395184278.x

Maharani, H. R. (2014). Creative Thinking in Mathematics: Are We Able To Solve Mathematical Problems in a Variety of Way? International Conference on Mathematics, Science, and Education.

Mugisha, S., Doungmo Goufo, E. F., \& Mogari, L. D. (2014). Analysis of the performance of first year students in Calculus. International Journal of Engineering Education.
Palinussa, A. L. (2013). Students' critical mathematical thinking skills and character: IndoMS.J.M.E.

Palupi, D. D., Sugiarti, T. \& Kurniati, D. (2017). Berpikir Kritis Dalam Memecahkan Masalah Terbuka Berbasis Polya Sub Pokok Bahasa Persegi Panjang Dan Persegi Siswa Kelas VII-B SMP Negeri 10 Jember. Kadikma, 8(3), 162-172.

Peter, E. E. (2012). Critical thinking: Essence for teaching mathematics and mathematics problem solving skills. African Journal of Mathematics and Computer Science Research.

https://doi.org/10.5897/AJMCSR11. 161

Purwati, R., Hobri., \& Fatahillah, A. (2016). Analisis Kemampuan Berpikir Kritis Siswa dalam Menyelesaikan Masalah Persamaan Kuadrat pada Pembelajaran Model Creative Problem Solving. Kadikma, 7(1), 84-93.

Ridwan, M. (2017). Profil Kemampuan Penalaran Matematis Siswa Ditinjau dari Gaya Belajar. KALAMATIKA Jurnal Pendidikan Matematika. https://doi.org/10.22236/kalamatika. vol2no2.2017pp193-206

Sherafat, R. (2015). Critical Thinking, Reasoning, and Logical Concluding' Abilities in relation to Academic Achievement among Indian Adolescent Students. The International Journal of Indian Psychology, 3(1), 145-155.

Sulistiani, E., \& Masrukan. (2016). Pentingnya Berpikir Kritis dalam Pembelajaran Matematika untuk Menghadapi Tantangan MEA. Seminar Nasional Matematika $X$ Universitas Negeri Semarang 2016.

Van Roekel, D. (2014). Preparing 21st Century Students for a Global Society: An Educator' $s$ Guide to the "Four Cs." National Education Association.

Yuniar, Siti Nastiti; Sunardi; Kurniawati, D. (2017). Pengembangan Indikator 4C's yang Selaras dengan Kurikulum 2013 SMA Kelas X Pada Materi Trigonometri. Kadikma, 8(3), 173-185. 